\title{
FLOODPLAINS AND PALEOSOLS IN THE WYOMING EOCENE SEQUENCE: IMPLICATIONS FOR THE TAPHONOMY AND PALEOECOLOGY OF FAUNAS
}

BOWN*, Thomas M., U.S.G.S., Denver, CO 80225, U.S.A.; KRAUS, Mary J., ASLAN, Andres, Dept. of Geological Sciences, U. of Colorado, Boulder, CO 80309, U.S.A.

The Willwood Fm. of the southern Bighorn Basin of Wyoming, U.S.A., comprises $700 \mathrm{~m}$ of lower Eocene alluvial molasse, nearly all of which contains relict pedogenic features. These rocks are grouped into pedofacies--alluvial sediment prisms, thick with immature paleosols proximal to streams and thinner with mature paleosols distally. Pedofacies are bounded by either trunk-stream channel or crevasse-splay deposits, which represent time-stratigraphic markers. The floodplain widths of the Willwood rivers varied from 15 to $20+\mathrm{km}$. Paleosols occur throughout the Willwood Formation and the most mature paleosols required about $60 \mathrm{Ka}$ to form whereas the least mature, required 0.5 to $1.0 \mathrm{Ka}$. Paleosol thicknesses vary from about $0.3-8.0 \mathrm{~m}$ and are directly related to net sediment accumulation rate (NSAR) and profile maturity. Pedofacies also reflect NSAR controls; pedofacies are continuously superposed, 15-35-m-thick, and represent time intervals of $30-60 \mathrm{Ka}$.

In the earliest Eocene, paleosol maturity rose sharply, and NSAR plummeted (Fort Union Fm./Willwood Fm. contact), after which maturity gradually declined (and NSAR rose) throughout the early Eocene. This decline was punctuated by two episodes of severe decline, each corresponding with major increases in NSAR, increased tectonism, and episodes of faunal turnover ("Biohorizons" A and B). Above the biohorizons, species earlier tied to particular paleosol maturities were replaced by closely related though more generalized species with no marked paleosol preferences. Time-stratigraphic reconstruction of the Willwood Fm. shows that "Biohorizons" B and C record the same faunal event; $\mathrm{B}$ the extinctions, and $\mathrm{C}$ the immigrations.

The 1,300 Willwood fossil vertebrate localities, which are distributed throughout the entire formation, occur in the surface horizons of cumulative alluvial paleosols. All fossil accumulations in paleosols are attritional and formed during pedogenesis. The most complete remains occur in immature paleosols, whereas the most abundant remains are found in mature paleosols. Within the large-scale Willwood ecologic setting, studies of discrete (m's to tens of m's thick) stratigraphic intervals suggest that the paleontology and sedimentology of these intervals can be significantly influenced by lateral differences in paleosol hydromorphy (soil wetness) and maturity (lateral position of a fossil-bearing paleosol with respect to an ancient river channel). These smaller-scale controls on fossil occurrences are important for distinguishing between real and apparent changes in faunal compositions over time and emphasize the value of threedimensional stratigraphic analysis for interpreting paleontologic events.

Supported by National Geographic Society grant 3985-89. 